Preservation from 1954-1966, and chairman of the Italian National Section for thirty-five years, only relinquishing this position in 1970 on account of ill health, when he was immediately elected honorary president of the section.

Ghigi was a great traveller until just before he died, and attended many international conferences. In 1968, at the age of 94 , he attended a conference in Venezuela in March, followed by another in Hungary in May, and a third in Rumania in June. Ghigi was an outstanding personality wherever he went, and he will be mourned all over the world.

\section{Academician A. I. Mikoyan}

ACAdemician Artem Ivanovich Mikoyan, one of the leading aircraft designers of the Soviet Union, died on December 9, 1970.
Mikoyan was born in 1905, in the village of Sanain, in Armenia. He was educated at the Zhukovskii Air Force Engineering Academy. In 1937 he became head of the design department of the experimental aircraft design bureau, and subsequently rose to be chief designer and director. In 1945, he visited Germany to study German aircraft construction methods. He was elected to the Academy of Sciences as a Corresponding Member in 1953. Together with M. I. Gurevich, he designed the series of MiG fighter aircraft. His first design for a turbojet aircraft was completed in 1946. From 1954 onwards he designed numerous types of supersonic aircraft.

For his services to the aircraft industry, Mikoyan received three Stalin Prizes (now State Prizes), one Lenin Prize, the Order of Lenin (5 times), four other Orders and a number of medals. He was twice nominated as a Hero of Socialist Labour.

The council of the Geological Society of London has announced the following medal awards for 1971: Wollaston Medal, to Brigadier R. A. Bagnold, for his contributions to the science of sand movement and its application to sedimentology and engineering problems; Murchison Medal, to Professor B. C. King, for his contributions to petrology and African geology; Lyell Medal, to Professor P. Allen, for his work in sedimentology; Bigsby Medal, to Dr F. J. Vine, for his contributions to the understanding of the evolution of the ocean floor. The proceeds of the Murchison Fund have been awarded to Dr J. Dewey, for his contributions to the understanding of the Lower Palaeozoic of the North Atlantic Province. Moieties of the Lyell Fund have been awarded to Dr G. Evans, for his work on recent coastal sedimentation, to Dr J. M. Hancock, for his work on the Cretaceous rocks of the British Isles, and to Mr T. R. Owen, in recognition of his services in the teaching of geology.

The recipients of the 1970 National Medal of Science, awarded by the US Government for distinguished achievement in science, have been announced: Professor R. D. Brauer, Harvard University; Professor Robert H. Dicke, Princeton University; Barbara McClintock, Carnegie Institution of Washington; George E. Mueller, General Dynamics Corporation; Albert B. Sabin, Weizmann Institute of Science, Rehovoth; Allan R. Sandage, Carnegie Institution of Washington; Professor John C. Slater, University of Florida; Professor John A. Wheeler, Princeton University; and the late Professor Saul Winstein, University of California
British Diary

Monday, February 22

Concorde (6.30 p.m.) Mr B. Trubshaw, Institution of Electrical Engineers, London Graduate and Student Section, jointly with I.Mech.E., at I Birdcage Walk, London SW1.

Semiconductor Nuclear Devices (2.30 p.m. colloquium) Institution of Electrical Engineers, at Savoy Place, London WC2.

Tuesday, February 23

Cable Installations Designed by Computer Techniques (5.30 p.m. discussion) Institution of Electrical Engineers, at Savoy Place, London WC2.

Experiences with Electrostatic and Mechanical Dust Collectors (6 p.m. discussion) Institution of Mechanical Engineers, at 1 Birdcage Walk, London SW1.

Faraday and the Beginning of Useful Electricity (3 p.m.) Professor R. King, Royal Institution, at 21 Albemarle Street, London W1. (Lecture for Preparatory School Pupils from Schools in London and the Home Counties. To be repeated on February 24 and 25.)

Respiratory Viruses (5.30 p.m.) Dr D. A. J. Tyrrell, University of London, at the Institute of Child Health, 30 Guilford Street, London WC1. (Fourteenth of fifteen lectures on "The Scientific Basis of Medicine" organized by the British Postgraduate Medical Federation.)

The New Anthropology and Its Critics (5 p.m.) Mr Edwin Ardener, University of London, at the London School of Economics and Political Science, Houghton Street, London WC2. (Malinowski Memorial Lecture.)

Wednesday, February 24

Built-in Test Equipment for the Concorde (6 p.m. discussion) Institution of Electrical Engineers, at the Royal Aeronautical Society, 4 Hamilton Place, London W1.

Culpeper's Herbal: Over Three Centuries (1 p.m.) Dr F. N. L. Poynter, Royal Institution, History of Science Discussion Group, at 21 Albermarle Street, London W1.

Environment of Packages in Transit (2.30 p.m. symposium) Society of Environmental Engineers, in the Mechanical Engineering Department, Imperial College, London SW7.

Food Additive Specifications (6.15 p.m.) Dr H. Egan, Society of Chemical Industry, Food Group, at 14 Belgrave Square, London SW1.

Long Distance Waveguides (6.30 p.m.) $\mathrm{Mr}$ N. Lacey, Institution of Electrical Engineers, London Graduate and Student Section, at Croydon Technical College, Fairfield, Croydon, Surrey. 